\title{
Online innovation and repurchase intentions in hotels: the mediating effect of customer experience
}

\author{
George Kofi Amoako \\ Marketing, University of Professional Studies, Accra, Ghana \\ Joshua Kofi Doe \\ Marketing, Central University, Accra, Ghana, and \\ Emmanuel Kotey Neequaye \\ Simon Page College of Marketing, Accra, Ghana
}

\begin{abstract}
Purpose - This study investigates how customer experience mediates the relationship between online innovation and repurchase intention in the hotel industry in Ghana.

Design/methodology/approach - Data was collected from 167 clients from a two-star hotel in Accra, the capital city of Ghana. Structural equation modelling was used to analyse the relationship between the variables. Findings - Results from the analysis indicate that online innovation positively leads to higher repurchase intentions and better customer experience, affirming that customer experience leads to repurchase intentions. Thus, while online innovation leads to repurchase intentions, the strength of this repurchase intention depends on customer experience. Therefore, customer experience mediates the relationship between online innovation and repurchase intention in the hotel industry.

Research limitations/implications - This study addressed only the customer's point of view; future studies could investigate the subject from the managers and other stakeholders' point of view to get a holistic view. Also, the sample size could be improved, and the study could be conducted in other African countries for comparison purposes.

Practical implications - The study shows that online innovation does not automatically lead to increased positive repurchase intention. Hotel managers must, therefore, enforce good customer experience for better profitability.

Originality/value - As far as the researchers know, limited studies have been conducted into how customer experience mediates online innovation and repurchase intention in the hotel industry in Ghana using structural equation modelling. This makes this research unique in Ghana. This study makes an original contribution by measuring the real effect of innovation on repurchase intentions in the hotel industry in Ghana.
\end{abstract}

Keywords Online innovation, Repurchase intention, Customer experience, Hotel industry, Ghana

Paper type Research paper

\section{Introduction}

The growth of the Internet technology pushed businesses into an electronic era, changing how consumers communicate, shop, buy and evaluate products and services (Kim and Lennon, 2008). The Internet has become the fastest-growing retail channel (Kim and Lennon, 2008). The recent phenomenal increase in the use of smart devices such as smartphones, tablets and other smart objects, reaching 17.6bn in 2016 (Statista, 2017), also means a growing connectedness of device types (Vermesan and Friess, 2013). The interconnectedness of

(c) George Kofi Amoako, Joshua Kofi Doe and Emmanuel Kotey Neequaye. Published in International Hospitality Review. Published by Emerald Publishing Limited. This article is published under the Creative Commons Attribution (CC BY 4.0) licence. Anyone may reproduce, distribute, translate and create derivative works of this article (for both commercial and non-commercial purposes), subject to full attribution to the original publication and authors. The full terms of this licence may be seen at http:// creativecommons.org/licences/by/4.0/legalcode

Received 6 February 2021 Revised 12 May 2021 22 June 2021

Accepted 13 July 2021 innovation and repurchase intentions 
"everything" has changed value creation functions in firms, creating opportunities for firms and the society (Spohrer, 2016). Thus, new service establishments, facilitated by the convergence of big data, mobile solutions, cloud computing, cognitive computing and the IoT/IoE, draw substantial attention because they offer many promising ways for actors to innovate (Demirkan et al., 2015; Ng and Wakenshaw, 2017). As hotel consumers use such technologies and continually shift towards mobile devices for travel planning and booking, hotels also need to make adjustments on their websites to meet their customers' expectations (Stringam and Gerdes, 2019). Studies have also shown that digital marketing is part of the current trends in the hotel industry (Mkwizu, 2019). Further, in this post-COVID-19 lockdown era, a contactless, flexible and customisable platform such as websites that can attend to front-office operations is a handy solution that the industry needs (Rahimizhian and Irani, 2020).

Even though the literature on digital technology innovations addresses many technical issues (Vermesan and Fries, 2014), business scholars have just begun to examine the impact of these innovations ( $\mathrm{Ng}$ and Wakenshaw, 2017) on consumer purchases and repurchase intentions, particularly in the hotel industry. For instance, Bae et al. (2020) investigate factors that influence the adoption or rejection of digital technologies such as smartphones in the hotel industry. This study utilised the technology adoption model and did not focus on the customer experience. Also, Stringam and Gerdes (2019) examined the disparity between how hotel websites load on various platforms and found significant differences that can affect the service experience of guests. They suggested consistent further research on the total experience of hotel websites since website technologies keep evolving and vary widely between hotels. Again, Chen et al. (2020) also studied the effect of person-to-person interaction on repurchase intention in a hotel setting and recommended that future studies examine the effect of other forms of interactions, such as digital interactions (social media, websites, etc.) on service experience and its effect on repurchase intention, in the post-COVID-19 era.

In Ghanaian context, for instance, Boateng and Narteh (2016) have examined the impact of online relationship marketing on affective customer commitment, with online channel trust as the mediator. They found that the experience of trust mediates the influence of engagement and personalisation on affective commitment. Similarly, Danso et al. (2018) have examined the extent to which social media platforms are used for purchase activities. They found that these online innovations positively influence purchase and consumption intentions through satisfaction experience. In studies from other parts of the world, Pereira et al. (2016) found that customer satisfaction mediates the relationship between online purchase determinants and customer loyalty. Ebrahim et al. (2016) also found that consumer perceptions and consumers' experiential responses towards brands influence brand repurchase intentions.

Some previous research has been done on how websites influence customer behaviour. For instance, Back et al. (2020) have demonstrated how the Internet has become the primary source of information search for the location and reservation of hotel accommodation. Lee (2018) examined how telepresence influenced customers' attitudes towards hotels' website and behavioural intentions. Lehto et al. (2018) study the extent of convergence in website quality perception across different cultures. Perhaps a pointer to the relevance of this study is Li et al.'s (2017) argument that customer perception and experience on economy hotels' website can be different from that of luxury hotels' websites. Li et al. (2017) further argued that a hotel's website's quality has a significant and positive impact (Li et al., 2017) on purchase intention. This is known as a pre-service encounter effect. However, much research has not been conducted to examine how the online experience during and after a service encounter influences repurchase intention.

Thus, different studies have reported how various aspects of customer experience mediate the relationship between purchase factors and repurchase intention or loyalty (Lemon and 
Verhoef, 2016; Edelman and Singer, 2015). Likewise, other studies have assessed how hotel website influences purchase intention (Lee, 2018; Lehto et al., 2018). None of these studies, however, has examined how customer experience mediates the relationship between online innovation and repurchase intentions. This study, therefore, attempts to fill this research gap. The research question we seek to answer in this study is whether online innovation leads to repurchase intention through the influence of the experiences created by the innovation. The study describes the hotel industry in Ghana, the literature on customer repurchase intention, customer experience and innovations to develop a hypothesis to be tested with data.

\section{Alisa Hotels and the Ghana hotel industry}

At the Apex of Ghana's tourism industry is the Ministry of Tourism. The ministry is assisted by government agencies such as the Ghana Tourist Authority, Hotels and Caterers Training Institute (HOTCAT) and Ghana Tourism Development Agency. Also, the ministry oversees private tourism firms, which are collectively called Ghana Tourism Federation (GHATOF), the umbrella body of all private tourism firms in Ghana who are usually grouped into associations such as hotels (Ghana Hotels Association), tour operators (Tour Operators Union Of Ghana) and car rentals (Car Rentals Association of Ghana), among others. The total contribution of the Travel and Tourism industry to GDP was GH $\notin 12,573.3 \mathrm{mn}$ (US $\$ 864.1 \mathrm{~m}$ ), $6.2 \%$ of GDP in 2017 . This is forecasted to grow by $4.9 \%$ in 2018 , and an average of $4.2 \%$ per year to GHC19, 852.8m (US\$4,522.3m), 5.7\% of GDP by 2028 (www.wttc.org).

According to the Ghana Tourism Authority, there are five taxonomies of accommodation facilities, which are one star (fourth class), two-star (third class), three-star (second class), four-star (first class) and five-star (luxury) hotels (www.touringghana.com). Available data shows growing use of online technologies in the search, evaluation, purchase and postpurchase evaluation of hotel services from the demand side (customers) and an equal measure of service delivery sophistication using online technologies from the supply side (service firms) (Xiang and Gretzel, 2010; Park and Allen, 2013; Bilgihan and Bujisic, 2015; Zervas et al., 2017; Bruni et al., 2017). Again in the hotel industry, over 75\% of hotels utilise social media in their marketing efforts (Friebe and Campbell, 2010).

As more hotels incorporate social media and other digital innovations into their integrated marketing communications, the attention on its effectiveness is rising. An uncharted research gap exists in how customers' online experience impacts their repurchase intention through the differential experience of being online. Hence, this study seeks to fill this research gap, using a Ghanaian hotel, Alisa Hotels, which has grown from a one-star hotel to a four-star hotel (www.alisahotels.com).

Alisa Hotels is a chain of hotels with three locations. From its two-star facility, the hotel chain has expanded to include two four-star hotels facilities in different locations (www. alisahotels.com). The hotel chain uses the same website to market all its three locations. The standard features on two-star hotels' websites are room availability and a booking menu, information on available facilities and the hotel's contact details. Thus, while some of the features on Alisa Hotels' website are considered to be standard in the case of four-star facilities, they are deemed by customers of a two-star hotel in Ghana to be a market-leader innovation. To start with, Alisa Hotels has a large banner on its homepage that says "Book Now". Booking menus on websites are standard, but banners that prompt visitors to make reservations are not common for two-star hotels in Ghana. Alisa Hotels' website has been linked to its social media pages. The website has communication feeds from its Instagram, Facebook and Twitter pages. From these social media feeds, their customers can share their pictures, events and comments based on their experiences in the hotel. It also uses social media tags such as "ALISACARES”, "ALISAHOTELS", "FOOD”, "GOODFOOD”, "TASTY", "HOTEL”, "DESSERTS”, "DRINKS”, “ACCRA”, "TEMA” and "Ghana” on its website. The 
hotel shows up in search results for these tags. These promote post-service encounter engagements or relationships with the hotel. The hotel's website is also used to promote health and safety issues. Currently, it has detailed information available for customers on what it does to promote COVID-19 protocols and what customers must do in co-producing services. Recent literature shows that customer perception and experience on economy hotels website can be different from luxury hotels' websites (Li et al., 2017). In this particular context, the features listed are not the standard features on two-star hotels' websites in Ghana and hence making it an innovation to that market.

\section{Literature}

\section{Theoretical foundation}

The Traditional Macro-Model of Customer Satisfaction (Woodruff and Gardial, 1996) opines that customer satisfaction outcomes, such as repeat purchase, word of mouth, referrals and even complaints, are precipitated by a positive or negative disconfirmation of a trade-off between perceived performance of the service organisation and standard expectation of service performance. The trade-off between perceived performance and expected performance will lead to satisfaction, which is precipitated by positive disconfirmation and subsequent repurchase intention. Following this model, we propose that hotel services' repurchase intention will be precipitated by customer satisfaction and the service innovation experience.

Hotel clients' experiences can be illustrated in four dimensions of hedonics, peace of mind, involvement and recognition (Chen et al., 2020; Otto and Ritchie, 1996). Thus, a hotel's website is expected to deliver these values as part of the customer experience. The Consumer Experience Index (Kim et al., 2011) also exploits seven experience dimensions of customer experience with include the environment, benefits, convenience, accessibility, utility, incentive and trust to measure service experience. Another model that is to understand hotel customers' experience is the "Tourist Experience Driver Model" (TEDM) (Chen et al., 2014). The TEDM uses trip-embarkation experiences (pre-service encounter and service encounter stages) and trip reminiscing experiences (post-service encounter stage) as aspects of service encounter that influence hotel repurchase intentions. In this model, Chen et al. (2014) argue that there are three categories of drivers that could affect the pre-encounter and service encounter stages of hotel guests: personal, environmental and interactive drivers. The interactive drivers, including website interaction experiences, could increase tourists' enjoyment of a destination, such as a hotel.

\section{Consumer repurchase intention}

The consumer decision-making processes involve a series of cognitive actions before a consumer makes a purchase decision (Schiffman and Kanuk, 2010). This process involves problem or need recognition, the search of relevant information, evaluation of information, purchase and post-purchase evaluation (Engel et al., 1986). The outcome of the purchase decision, however, either leads to cognitive dissatisfaction and subsequent rejection of product, or satisfaction and, therefore, a repurchase intention (Schiffman and Kanuk, 2010). Customer satisfaction (Kotler, 1994) is the individual sensation of pleasure as a result of comparison between a product's expectations and its performance. This occurs based on a customer's post-purchase experience evaluation. Kotler (1994) asserts that the key issue that affects customer retention, and thus, repurchase intention (Hennig-Thurau and Klee, 1997), is customer satisfaction. Therefore, the initial purchase and usage experience of a customer will lead to either a repurchase or rejection intention. Repurchase intention is the decision to rebuy a product or service regularly in the future; thus, leading to a repetition of brand purchase or 
brand-set purchase (Oliver, 1999). A repurchase intention occurs at the cognitive, affective, conative (behavioural intention) and action (actual behaviour) levels. The link between customer satisfaction and post purchase intention has been established in several studies (Kuo et al., 2009; Zeithaml et al., 1996; Cronin et al., 2000).

\section{innovation and Online repurchase intentions}

\section{Innovation}

Innovation is the process of making improvements to a product, service or process, resulting in the introduction of a new element for the organisation, thereby adding value to customers and contributing to the knowledge store of the firm (O'Sullivan and Dooley, 2008). Innovation is also defined in the Oslo Manual by OECD (2005) as the application of novel or expressively enhanced product, or procedure, a new marketing technique or new organisational technique. Thus, innovation can be product innovation, process innovation, marketing innovation or organisational innovation (Schmidt and Rammer, 2006). Schumpeter (1934) describes innovations as the "carrying out of new combinations". Other authors also view it as the creation or adoption of an idea, material artefact, behaviour, product, technology or a process that is new to the adopting unit (Gupta et al., 2007). This view invariably suggests that innovations are not completely new, but newer combinations of processes, methods, technologies, among others. But, who is it new to, and in what way is it new? According to the discussion in Johannessen et al. (2001), both radically new and incrementally new innovations (Schumpeter, 1934) can be new to the customer, new to the market, new to the firm or even new to the industry. Thus service innovation - whether it is an addition to existing services or a change in the delivery process - is a previously unavailable to customers offering that necessitates changes in the competencies used by service providers and customers (Ordanini and Parasuraman, 2011). As a result, what counts as an innovation is also determined by the status and background of the adopting unit. Jensen et al. (2007), for example, note that threefourths of the new innovations reported by firms were already known on both the national and international markets. Amara and Landry (2005) emphasise the importance of categorising innovations based on their degree of novelty, because, as they point out, more and more firms can now be labelled as innovative in some sense. Thus, when a previously unavailable application on a website is introduced, it can be classified as an innovation, especially if it is not common in that segment of the market.

Digital innovation is an innovation empowered by digital innovations that lead to the formation of new forms of digitalisation (Yoo et al., 2010). In this study, we focus on the website of a Ghanaian hotel and the experiences it delivers to its customers from the pre-encounter stage, service encounter stage and post-encounter stages of service delivery. During the pre-encounter stage, various information is provided to potential customers regarding room rates and hotel facilities, among others, to enable them to make a purchase decision. During the encounter stage, the website is able to deliver other daily updates for customers, as well as information on where, how and when particular services are delivered and by who. Post-encounter deliverables of the website include feedbacks and CRM packages that customers can subscribe to.

According to Back et al. (2020), travellers use the Internet as their primary source of information to find locations and make hotel reservation. Different dimensions of a hotel's site influence consumer behaviour. Most hotel websites have the same features, especially economy hotels. However, Lee (2018) reports that telepresence, an innovation that is largely absent from economy hotel websites, influences customers' attitudes towards hotel websites and their behavioural intentions. Again, luxury hotel brand websites are regarded as an excellent platform for marketers to establish a positive brand identity (Lehto et al., 2018). The setup, outline, content and interactive pattern that support successful customer website experience are referred to as configuration (Zhang et al., 2021). The configuration of a 
website is perceived by the customer within the customer interface. Components of this website interface are content (text, pictures, sound and video that webpages contain), community (the ways sites enable user-to-user communication), customisation (site's ability to self-tailor to different users or to allow users to personalise the site), communication (the ways sites enable site-to-user communication or two-way communication), connection (degree site is linked to other sites), commerce (site's capabilities to enable commercial transactions) and context (site's layout and design) (Rayport and Jaworski, 2003).

The drivers of such innovation can be summarised as emerging technologies, competitor actions, novel ideas from customers, strategic partners, employees and emerging changes in the macro-environment.

Consumer acceptance and use of innovation are posited to be caused by the ease of use and usefulness (Venkatesh et al., 2012), social influences (Shih et al., 2013) and behavioural control (Taylor and Todd, 1995). In a study of how factors connected to mobile innovation influence customers in the banking industry, Saleem and Rashid (2011) found that the higher the level of technological innovation associated with a marketing product's consumption, the higher the level of satisfaction the customer observes. Thus, innovations leads to higher satisfaction and, subsequently, a higher tendency for repurchase. We, therefore, hypothesise that:

H1. Website innovation has a positive influence on repurchase intentions.

\section{Customer experience}

Customer experience, which includes customer satisfaction, service quality, relationship marketing and customer equity (Howard and Sheth, 1969), has been researched over the years under different topics. These include customer buying behaviour process: customer experience and customer decision-making as a process (1960-1970s), customer satisfaction and loyalty: customer perceptions and attitudes about an experience (1970s): service quality: elements of the customer experience and mapping the customer journey (1980s); relationship marketing: customer responses considered in the customer experience (1990s): customer relationship management (CRM): elements of the customer experience influence on business outcomes (2000s), customer centricity and customer focus design and customer experience management (2000-2010s) and customer engagement: customer's role in the experience (2010s) (Lemon and Verhoef, 2016). Management of customer experience includes its design and implementation. Customer experience serves as a critical building block to the overall customer satisfaction (Lemon and Verhoef, 2016). Various authors have highlighted the essence of customer experience management across customer touchpoints (Edelman and Singer, 2015; Rawson et al., 2013). In this regard, customer experience management depicts the cultural mindsets of designing activities to maximise customer experiences (Homburg et al., 2017) for various touchpoints (Lemon and Verhoef, 2016) with the goal of achieving and sustaining long-term customer loyalty (Lemon and Verhoef, 2016). The design of this study uses innovation, which has been posited to impact customer experience (Lemon and Verhoef, 2016). We, therefore, hypothesise that:

H2. Website innovation has a positive influence on customer experience.

\section{Customer experience and repurchase intention}

Meyer and Schwager (2007) define customer experience as customers' inner and personal reaction to any contact with a company and its marketing stimuli. Customer experience has been explored since 1988 when Zeithaml (1988) discussed perceived product quality. Zeithaml (1988) defines quality as a professed conclusion about a firm's overall excellence or superiority and cites product quality as a precursor of a professed value and subsequently, a purchase. The customer journey in consumption in service design (Voss et al., 2008) leads to 
the view that customers' perception may differ as they go through the customer experience journey (Berry et al., 2002). Academic research in this area has shown that value is not embedded in a product at the moment of exchange but, rather, is obtained through the experience journey or its usage processes (Vargo and Lusch, 2004; Tynan et al., 2010).

Customer experience comes from a set of exchanges between a customer and a company or its related products or services that initiates a reaction (Gentile et al., 2007). This experience is private and suggests the customer's involvement at different levels including sensory, rational, physical, emotional and spiritual levels (Gentile et al., 2007). Before a purchase, this exchange includes the experience of the marketing mix (Brakus et al., 2009) and the mediated experience of other customers through word of mouth (Kwortnik and Ross, 2007), contextual experience (Gilmore and Pine, 2002) or the encounter with the web medium (online innovations) (Sautter et al., 2004). The indirect interaction of customers after the service encounter embraces the consumption or user experience (Woodruff, 1997). Customer experience, therefore, encompasses the overall consumer purchase know-how, including the information search, purchase, usage and after-sale stages of the experience (Verhoef et al., 2009). In effect, this experience is shaped by both the manageable elements of the marketing environment and the uncontrollable elements such as the influence of other shoppers.

Cowley (2008) also demonstrated that customer experience may be viewed retrospectively as more constructive to vindicate the desired repeat purchase. Thus, where customer experience is positive, it has an influence on a repeat purchase intention. Customers' website impressions and experiences, therefore, have become significant in the hospitality industry where customers may not have any other means of tangible interaction before the service encounter (Stringam and Gerdes, 2019). This is because customers' performance expectations of a hotel's website directly influence the behavioural intentions to continue to use the website or patronise the hotel (Stringam and Gerdes, 2019). We, therefore, hypothesise that:

H3. Customer experience has a positive influence on repurchase intentions.

While some studies (Homburg et al., 2017; Lemon and Verhoef, 2016) have found the design of customer experience, specifically online innovations, as an essential component of the customer experience construct, other studies have found that the customer experiences, such as trust and satisfaction (Chinomona, and Dubihlela, 2014), information searching cost, moral hazard cost and specific asset investment (Wu et al., 2014) positively lead to repurchase intention and loyalty. The implication of these findings is that online innovation could lead to repurchase intention and enhanced customer experience. Thus, if customer experience leads to repurchase intention (Chinomona, and Dubihlela, 2014; Wu et al., 2014), then customer experience could become a mediator between innovations and repurchase intention. We, therefore, hypothesise that:

H4. Customer experience mediates the relationship between innovations and repurchase intentions.

\footnotetext{
Methodology

Instrument development

There were three latent variables in our research model, each was measured with multiple items. In order to improve content validity, these items were adapted from existing literature (Straub et al., 2004). The items were then re-worded to reflect the context of current the study. With the aim of making the survey questions "respondent friendly" and comprehensible, the questionnaire was first reviewed by experienced professionals in the hospitality industry and researchers with expertise on the subject matter. Comments from these experts were considered in revising the question items.
} 
The three items used to measure trust, which reflects the belief that the hotel will not behave opportunistically by taking advantage of the situation, were adopted from Park et al. (2017). Satisfaction was also measured with three items derived from Xu et al. (2015). The items used to measure repurchase intension were derived from Tolba (2011) and Knight and Kim (2007). The items for measuring customer experience were adopted from Voss et al.(2003) and Mathwick et al. (2001). All items were presented in English and measured using a seven-point Likert scale, strongly disagree (1) and strongly agree (7).

\section{Sample and data collection}

Data was collected through a survey conducted over 2 months at Alisa Hotel in Labone, Accra. This is a two-star rated facility, which is part of the Alisa Hotels chain. Guests who have had previous engagements with the hotel website and were willing to participate in our study were given questionnaires to fill out. Respondents (guests) also had the opportunity to ask clarification on any question item. A sample of 200 customers of the hotels was randomly selected from the list of customers. However, due to missing values, a total of 167 valid responses were used for analysis. Out of the valid responses, 102 were males, while 65 were females (see Table 1). Each respondent was required to have had at least five (5) years of continued patronage of the hotel and used their website over the period. Respondents are basically from over thirty two countries (see Table A1, Appendix). A structured questionnaire was used to collect data from respondents to examine how their online experience as customers impacts customer repurchase intention. The structured questionnaire utilised a seven-point Likert scale that ranged from $1=$ strongly disagree to $7=$ strongly agree. Data collected was analysed using partial least squares-structural equation modelling (PLS-SEM).

\section{Data analysis}

Due to the relatively high response rate, a test for non-response bias was not undertaken (Leden et al., 2011). However, a test for common method variance bias was undertaken since data for this research was gathered using a single questionnaire. This study performed Harman's (1967) one-factor test based on the method defined by Podsakoff et al. (2003). Exploratory factor analysis with the extraction of only one factor showed that the factor accounted for about $40 \%$ of the variance explained (which is less than $50 \%$ variance). In the analysis of data, PLS was used (SmartPLS Release: 3.2.7 (Ringle et al., 2015). PLS is suited for predictive models using very small or huge samples (Chin, 1998; Hair et al., 2011) and is the favoured method when assumptions of normality are not satisfied (Wold, 1982; Chin and Newstead, 1999). The significance of each path was tested using bootstrap t-values $(5,000$ sub-samples) (Efron and Gong, 1983; Tortosa et al., 2009), a procedure available in PLS.

\section{Confirmatory factor analysis}

Analysis of the scale items showed that one (1) item had kurtosis $> \pm 1.0$, whereas one item had skewness $> \pm 1.0$. More importantly, the Kolmogorov-Smirnov test of normality showed $0.172<\alpha<0.275 ; p<0.01$ for all items. Similarly, the Shapiro-Wilk test of normality was $0.826<W<0.933 ; p<0.01$ for all items. These imply that the data is not normally distributed as a result, PLS-SEM was used to perform confirmatory factor analysis and SEM. Cronbach's alpha, composite reliability and average variance extracted estimates all met the minimum of 0.7, 0.7 and 0.5, respectively, recommended by Hair et al. (2016), as show in Table 2. Also, each of the item loadings for the scale used was statistically significant using bootstrap $t$-values (5,000 sub-samples) (see Figure S1 in supplementary file) (Tortosa et al., 2009). The results imply that convergent validity has been adequately met (see Table 3 ).

Next, discriminant validity is met by the fact that the square root of the average variance extracted estimates for each of the three constructs is greater than the inter-construct 


\begin{tabular}{|c|c|c|c|}
\hline Variables & Frequency & Percent & Online \\
\hline $\begin{array}{l}\text { Gender } \\
\text { Male } \\
\text { Female }\end{array}$ & $\begin{array}{r}102 \\
65\end{array}$ & $\begin{array}{l}61.1 \\
38.9\end{array}$ & $\begin{array}{r}\text { repurchase } \\
\text { intentions }\end{array}$ \\
\hline $\begin{array}{l}\text { Age group } \\
<21 \text { years } \\
21-30 \text { years } \\
31-40 \text { years } \\
41-50 \text { years } \\
51-60 \text { years } \\
>60 \text { years }\end{array}$ & $\begin{array}{r}3 \\
43 \\
54 \\
36 \\
29 \\
2\end{array}$ & \begin{tabular}{r|}
1.8 \\
25.7 \\
32.3 \\
21.6 \\
17.4 \\
1.2
\end{tabular} & \\
\hline $\begin{array}{l}\text { Marital status } \\
\text { Married } \\
\text { Single } \\
\text { Divorced } \\
\text { Total }\end{array}$ & $\begin{array}{r}81 \\
59 \\
27 \\
167\end{array}$ & $\begin{array}{l}48.5 \\
35.3 \\
16.2 \\
100\end{array}$ & $\begin{array}{r}\text { Table 1. } \\
\text { Background } \\
\text { information }\end{array}$ \\
\hline
\end{tabular}

\begin{tabular}{ll}
\hline Concept & Items \\
\hline Online innovation & $\begin{array}{l}\text { 1.1 Online branding of Alisa makes them standout } \\
\text { 1.2 Online activities of Alisa are user friendly }\end{array}$ \\
& 1.3 I like the online configuration of Alisa website \\
Customer & 1.4 Alisa's online website is attractive to customers \\
experience & 2.1 I am proud to be a customer of Alisa \\
& 2.2 Alisa Alisa's prices \\
Repurchase & 2.4 I am satisfies me any time I experience their services \\
intentions & 3.1 I will keep coming back to Alisa \\
& 3.2 I will recommend Alisa to my friends and colleagues \\
& 3.3 if Alisa charges slightly higher than its competitors for the same service, I will still \\
& come to Alisa \\
& 3.4 I plan maintaining a long term relationship with Alisa
\end{tabular}

Table 2.

Scales of variables in the model

\begin{tabular}{lcccccccc}
\hline Codes & Item & Mean & SD & Loading & Bootstrap $t$-values & $\alpha$ & C.R & AVE \\
\hline Online innovation & 1.1 & 5.012 & 1.326 & $0.970^{* *}$ & 131.859 & 0.960 & 0.971 & 0.892 \\
& 1.2 & 4.916 & 1.377 & $0.934^{* *}$ & 41.526 & & & \\
& 1.3 & 4.934 & 1.313 & $0.957^{* *}$ & 82.471 & & & \\
Customer experience & 1.4 & 4.832 & 1.365 & $0.916^{* * *}$ & 42.974 & & & \\
& 2.1 & 4.299 & 1.574 & $0.950^{* * *}$ & 59.039 & 0.963 & 0.973 & 0.900 \\
& 2.2 & 4.311 & 1.505 & $0.959^{* * *}$ & 77.640 & & & \\
Repurchase intentions & 2.3 & 4.359 & 1.518 & $0.969^{* * *}$ & 104.755 & & & \\
& 2.4 & 4.335 & 1.467 & $0.916^{* *}$ & 35.451 & & & \\
& 3.1 & 4.425 & 1.569 & $0.849^{* *}$ & 19.635 & 0.929 & 0.949 & 0.824 \\
& 3.2 & 4.467 & 1.488 & $0.935^{* *}$ & 60.190 & & & \\
& 3.3 & 4.222 & 1.474 & $0.903^{* *}$ & 27.117 & & & \\
& 3.4 & 4.353 & 1.473 & $0.943^{* *}$ & 68.429 & & &
\end{tabular}

Note(s): ${ }^{* *} t$-values are significant at $p<0.01$

Table 3.

Reliability and convergent validity 
correlations between them (Fornell and Larcker, 1981; Barclay et al., 1995). This shows that each construct is distinct and differs from the other measurement constructs in the model. See Table 4 for details.

Recent research on variance-based SEM has suggested that the Fornell and Larcker criterion alone is not conclusive on discriminant validity (Henseler et al., 2015); as a result, the author performed the heterotrait-monotrait ratio (HTMT) of the correlations to assess the items using a specificity criterion rate of 0.85 (HTMT0.85). The results presented in Table 4 show that none of the correlations exceeded 0.85; as a result, the three construct model demonstrates discriminant validity (see Figure 1).

\section{Structural model}

An examination of the model's predictive accuracy $\left(R^{2}\right)$ showed that online innovation explained about $33 \%$ of the variance in customer experience. Furthermore, both online innovation and customer experience explained about $44 \%$ of the variance in repurchase intentions. The results meet the minimum level of $33 \%$ variance suggested by Chin (1998) for good explanatory power. In addition to $R^{2}$, this study utilised cross-validated redundancy $\left(Q^{2}\right)$, a blindfolding procedure as a criterion for predictive relevance (Chin, 2010) of the endogenous variables. $Q^{2}$-values of 0.275 and 0.328 were obtained for customer experience and repurchase intentions, respectively, both of which are greater than 0 , showing predictive relevance (Fornell and Cha's, 1993; Chin, 2010). Finally, the effect sizes $\left(f^{2}\right)$ computed for the exogenous variables showed that online innovation had a large effect size on customer experience. In addition, online innovation had a small effect size on repurchase intentions, whereas customer experience had a medium effect size on repurchase intentions. The results of the predictive accuracy $\left(R^{2}\right)$, predictive relevance $\left(Q^{2}\right)$ test and effect sizes $\left(f^{2}\right)$ are presented in Table 5.

Table 4.

Discriminant validity (square root of AVEs in italic-diagonal)

\begin{tabular}{lccccc}
\hline & \multicolumn{3}{c}{ Fornell-Larcker criterion } & \multicolumn{2}{c}{ Heterotrait-monotrait ratio } \\
(HTMT) criterion & \\
Factor & 1 & 2 & 3 & 1 & 2 \\
\hline 1. Online innovation & 0.945 & & & & \\
2. Customer experience & 0.572 & 0.950 & & 0.595 & \\
3. Repurchase intentions & 0.501 & 0.641 & 0.908 & 0.524 & 0.671 \\
\hline
\end{tabular}

Figure 1.

Discriminant validity HTMT criteria

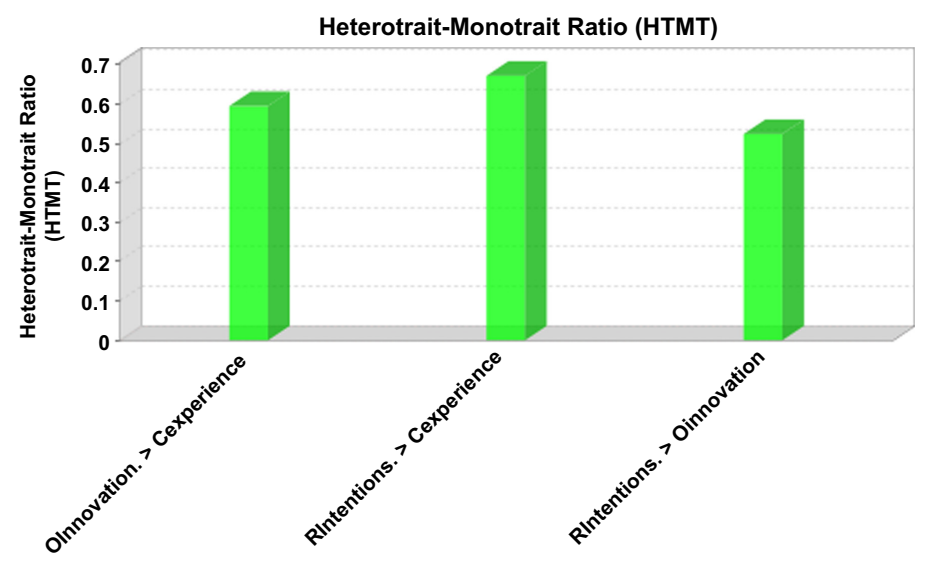


Hypothesis testing

The results of the structural model are presented in Table 6 and Figure 2 (See also Figure S2 on supplementary file). All paths are statistically significant; therefore, the first three hypotheses are confirmed in the present context. Specifically, a positive and significant relationship exists between online innovations, customer experience and repurchase intentions.

\section{Mediation test}

Following Nitzl, Roldan and Cepeda's (2016) recommendations for testing mediation in PLSSEM, customer experience partially mediates the relationship between online innovations and repurchase intentions. As a result, the fourth hypothesis is supported in the present context. The high proportion of mediation $(60 \%)$ indicates the importance of using innovation to build customer experience to facilitate repurchase intentions (see Table 7).

\begin{tabular}{|c|c|c|c|c|c|}
\hline Constructs & $R^{2}$ & $Q^{2}$ & $f^{2}$ (Customer experience) & $f^{2}$ (Repurchase intentions) & Table 5. \\
\hline Online innovation & - & - & 0.486 (large) & 0.05 (Small) & $\begin{array}{r}\text { Predictive accuracy } \\
\left(R^{2}\right) \text {, predictive }\end{array}$ \\
\hline Customer experience & 0.327 & 0.275 & - & 0.331 (medium) & relevance $\left(Q^{2}\right)$ and \\
\hline Repurchase intentions & 0.438 & 0.328 & - & - & effect sizes $\left(f^{2}\right)$ \\
\hline
\end{tabular}

\begin{tabular}{llccl}
\hline Hypothesis & Structural path & $\begin{array}{c}\text { Path } \\
\text { coefficient }\end{array}$ & $\begin{array}{c}t \text {-value } \\
\text { (Boostrap) }\end{array}$ & Hypothesis results \\
\hline $\mathrm{H} 1$ & $\begin{array}{l}\text { Online innovation } \rightarrow \text { Repurchase } \\
\text { intentions }\end{array}$ & $0.200^{*}$ & 1.990 & Supported \\
$\mathrm{H} 2$ & $\begin{array}{l}\text { Online innovation } \rightarrow \text { Customer } \\
\text { experience }\end{array}$ & $0.572^{* *}$ & 8.287 & Supported \\
$\mathrm{H} 3$ & $\begin{array}{l}\text { Customer experience } \rightarrow \text { Repurchase } \\
\text { intentions }\end{array}$ & $0.526^{* *}$ & 5.462 & Supported
\end{tabular}

Note(s): $* * t$-values are significant at $p<0.01 ; * t$-values are significant at $p<0.05$

Table 6. Structural path results

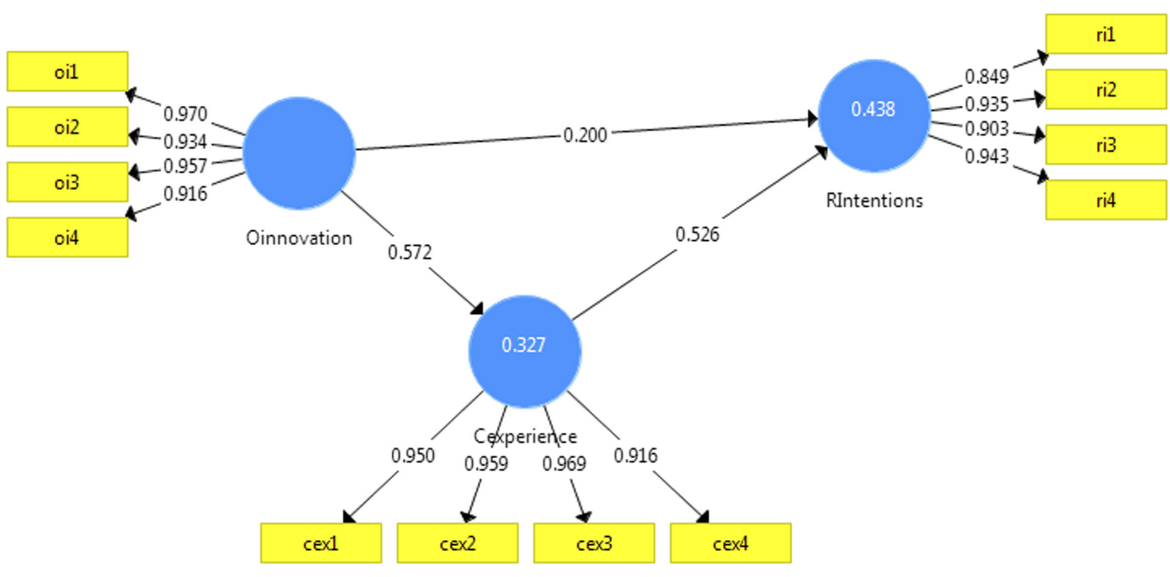

Figure 2. Structural model results 
IHR

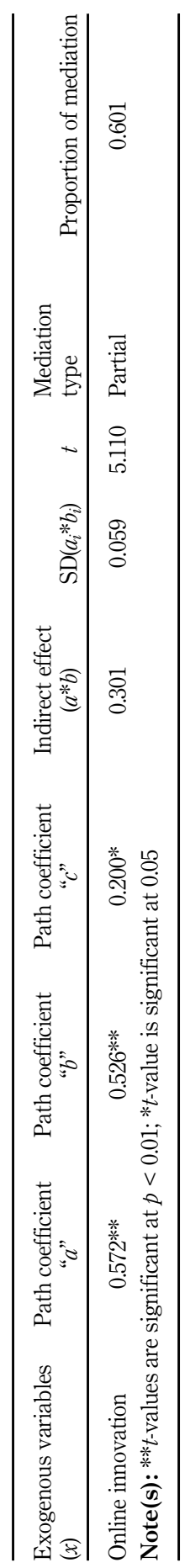

Table 7.

Mediation of customer experience on

innovation and

repurchase intentions 


\section{Discussion of findings}

This study sought to examine how customers' online experience impacts customer repurchase intentions. Specifically, the study tested the relationships between online innovation and repurchase intentions, online innovation and customer experience, customer experience and repurchase intentions, as well as customer experience as a mediator between online innovation and repurchase intentions. The results of the analyses are as follows:

\section{H1: Online innovation has a positive influence on repurchase intentions}

This hypothesis was supported by the data. The relationship between online innovation and repurchase intention was found to be significant at $p<0.05$. Per the structural paths in Table 3 , we conclude that online innovation positively leads to higher repurchase intentions.

\section{H2: Online innovation has a positive influence on customer experience}

This hypothesis was supported by the data. The relationship between online innovation and customer experience was significant at $p<0.01$. Structural path analysis in Table 3 also indicates that online innovation leads to a better customer experience. We conclude, therefore, that online innovation leads to a better customer experience.

\section{H3: Customer experience has a positive influence on repurchase intentions}

This hypothesis was also supported by data. A significant relationship was established for customer experience and repurchase intentions at $p<0.01$, with a structural path analysis confirming that customer experience leads to repurchase intentions.

\section{H4: Customer experience mediates the relationship between innovations and repurchase intentions}

Finally, data from this study affirmed that customer experience mediates repurchase intentions. The relationship between online innovation and customer experience has a path coefficient of $0.572 * *$, which is stronger than the relationship between online innovation and purchase intention with a path coefficient of $0.200^{*}$. The relationship between customer experience and repurchase intention is also confirmed with a path coefficient of $0.526^{* *}$. This relationship indicates that online innovation leads to repurchase intention; however, the repurchase intention is stronger when that relationship is mediated by customer experience. Thus, while online innovation leads to repurchase intentions, the strength of repurchase intention depends on the customer experience of an online innovation. Therefore, customer experience mediates between online innovation and repurchase intention.

\section{Contribution to theory}

This paper contributes to knowledge by providing empirical support to some earlier findings. The findings indicate that good customer experiences lead to repurchase intentions. This supports Kotler (1994) and other authors' (Kuo et al., 2009; Zeithaml et al., 1996; Cronin et al., 2000) assertion that customer retention, and thus, repurchase intention, is connected to customer satisfaction. The findings also show that the introduction of service innovation leads to better customer experience. This finding supports the findings of Saleem and Rashid (2011). They reported that the higher level of technological innovation associated with a product or service consumption, the higher the customer's level of satisfaction. While findings indicate that customer experience leads to service repurchase intention, this study's findings indicate that online innovation also leads to repurchase intention. This relationship is stronger when the online innovation and repurchase intention are mediated by customer experience.

\section{innovation and repurchase intentions}

Online 
Furthermore, this paper contributes to theory by extending the traditional Macro-Model of Customer Satisfaction by introducing customer experience as a mediator between service innovation and repurchase intention. This means that where innovation becomes an antecedent of customer experience, repurchase intention is guaranteed. The role of innovation as an antecedent of customer experience depicts the customer experience as a total journey (Voss et al., 2008) or process (Tynan et al., 2010; Vargo and Lusch, 2004) and not an event. Also, it confirms the Traditional Macro-Model of Customer Satisfaction's view of modelling the perceived performance of a service innovation as an antecedent of satisfaction and repurchase intention.

\section{Managerial implications}

Per the findings of this study, customer experience has a positive influence on repurchase intentions, and online innovation also leads to better customer experience. Although online innovations positively lead to higher repurchase intentions, this relationship is stronger when customers perceive a higher service experience, which is caused by online service innovation. Hence, hotel managers need to utilise online service innovations to enhance customers' service experience. This enhances service co-creation and shifts delivery powers to customers, ultimately resulting in repurchase intention and loyalty.

\section{Limitations and recommendations}

This study focussed on discussing online innovations, particularly the use of websites in the marketing and purchasing process in the hotel industry. The authors recommend replication of this study in other industries, using larger samples. Secondly, the study was based on a cross-sectional design; however, since customer experience may change over time, it would be interesting to consider a longitudinal study in the future. This could lead to a better understanding of customer experience. Also, online innovation may evolve over time since online business activities in Ghana and Africa are growing, and a longitudinal study will confirm customer behaviour over time. It is recommended that for future studies, service quality dimensions are used to explore the effect that each dimension has on customer experience and, consequently, repurchase intention. Furthermore, our respondents were asked to respond to construct variables that were only stated in the positive; hence, it will be interesting to utilise other variables such as mistrust, disappointment and brand hate to assess their effect on repurchase intention. This would present a more balanced view of customer experience and repurchase intention from consumers. Finally, the study sample was chosen from solely Ghana and a single hotel was studied. Thus, extending the study to other African countries and cities may confirm the study's findings within the broader hotel customer experience in the African context.

\section{References}

Amara, N. and Landry, R. (2005), "Sources of information as determinants of novelty of innovation in manufacturing firms: evidence from the 1999 statistics Canada innovation survey", Technovation, Vol. 25 No. 3, pp. 245-259.

Back, R.M., Park, J.-Y., Bufquin, D., Nutta, M.W.W. and Lee, S.J. (2020), "Effects of hotel website photograph size and human images on perceived transportation and behavioral intentions", International Journal of Hospitality Management, Vol. 89, doi: 10.1016/j.ijhm.2020.102545.

Bae, S., Mo Kwon, J. and Bosley, A. (2020), "Factors influencing consumers' rejection to smartphone transactions in the lodging industry", International Hospitality Review, Vol. 34 No. 1, pp. $29-40$. 
Barclay, D., Thompson, R. and andHiggins, C. (1995), "The partial least squares (PLS) approach to causal modeling: personal computer adoption and use an illustration”, Technology Studies, No. 2:2, pp. 285-309.

Berry, L.L., Carbone, L.P. and Haeckel, S.H. (2002), "Managing the total customer experience", MIT Sloan Management Review, Vol. 43 No. 3, pp. 85-89.

Bilgihan, A. and Bujisic, M. (2015), "The effect of website features in online relationship marketing: a case of online hotel booking", Electronic Commerce Research and Applications, Vol. 14 No. 4, pp. 222-232.

Boateng, S.L. and Narteh, B. (2016), "Online relationship marketing and affective customer commitmentThe mediating role of trust", Journal of Financial Services Marketing, Vol. 21 No. 2, pp. 127-140.

Brakus, J.J., Schmitt, B.H. and Zarantonello, L. (2009), "Brand experience: what is it? How is it measured? Does it affect loyalty?", Journal of Marketing, Vol. 73, pp. 52-68.

Bruni, A., Cassia, F. and Magno, F. (2017), "Marketing performance measurement in hotels, travel agencies and tour operators: a study of current practices", Current Issues in Tourism, Vol. 20 No. 4, pp. 339-345.

Chen, J.S., Prebensen, N.K. and Uysal, M. (2014), "Dynamic drivers of tourist experiences", in Prebensen, N.K., Chen, J.S. and Uysal, M. (Eds), Creating Experience Value in Tourism, 2nd ed., CAB International, Oxforshire, pp. 11-21.

Chen, Y.-L., Chen, J., Liu, W.-Y. and Sharma, T. (2020), "Expected benefits of people interactions and guest experiences", International Hospitality Review, Vol. 34 No. 2, pp. 187-202.

Chin, W.W. (1998), "The partial least squares approach to structural equation modeling”, Modern Methods for Business Research, Vol. 295 No. 2, pp. 295-336.

Chin, W.W. (2010), "How to write up and report PLS analyses", in Esposito Vinzi, V., Chin, W.W., Henseler, J. and Wang, H. (Eds), Handbook of Partial Least Squares: Concepts, Methods and Application, Springer, Berlin, pp. 645-689.

Chin, W.W. and Newsted, P.R. (1999), "Structural equation modeling analysis with small samples using partial least squares", in Hoyle, R. (Ed.), Statistical Strategies for Small Sample Research, Sage Publications, Thousand Oaks, CA, pp. 307-341.

Chinomona, R. and Dubihlela, D. (2014), "Does customer satisfaction lead to customer trust, loyalty and repurchase intention of local store brands? The case of Gauteng Province of South Africa", Mediterranean Journal of Social Sciences, Vol. 5 No. 9, p. 23.

Cowley, E. (2008), "Looking back at an experience through Rose-colored glasses", Journal of Business Research, Vol. 61, pp. 1046-1052.

Cronin, J., Brady, M. and Hult, T. (2000), "Assessing the effects of quality, value and customer satisfaction on consumer behavioural intentions in service environments", Journal of Retailing, Vol. 76 No. 2, pp. 193-218.

Danso, B.A., Xuhua, H., Addai, M. and Mensah, I.A. (2018), "Ranking social media utilization among tourists to improve marketing innovation using Bayesian posterior probability and maximum posterior probability procedure (MAP): evidence from the hospitality industry in Ghana", Canadian Journal of Applied Science and Technology, Vol. 6 No. 2, pp. 210-217.

Demirkan, H., Bess, C., Spohrer, J., Rayes, A., Allen, D. and Moghaddam, Y. (2015), "Innovations with smart service systems: analytics, big data, cognitive assistance, and the internet of everything", CAIS, Vol. 37, p. 35.

Ebrahim, R., Ghoneim, A., Irani, Z. and Fan, Y. (2016), "A brand preference and repurchase intention model: the role of consumer experience", Journal of Marketing Management, Vol. 32 Nos 13-14, pp. 1230-1259.

Edelman, D.C. and Singer, M. (2015), “Competing on customer journeys”, Harvard Business Review, Vol. 93 No. 11, pp. 88-100. 
Efron, B. and Gong, G. (1983), "A leisurely look at the bootstrap, the jackknife, and cross-validation", The American Statistician, Vol. 37 No. 1, pp. 36-48.

Engel, J.F., Blackwell, R.D. and Miniard, P.W. (1986), Consumer Behavior, 5th ed., Dryden, Hinsdale, IL.

Fornell, C. and Cha, J. (1993), "Partial least squares (PLS)", Unpublished Working Paper, University of Michigan Business School, Ann Arbor.

Fornell, C. and Larcker, D.F. (1981), "Evaluating structural equation models with unobservable variables and measurement error", Journal of Marketing Research, Vol. 18 No. 1, pp. 39-50.

Friebe, K. and Campbell, D. (2010), "Social media in the hospitality and Leisure Industry", DLA Piper Publication, available at: http://www.dlapiper.com/files/Publication/157721b8-d5ee-45ce-891111451f0738df/Presentation/PublicationAttachment/a9f81f84-7cbb-49c1-865d19c9283af4d3/ DLA_Piper_UK_Social_Media_in_Hospitality_and_Leisure_Sect or.pdf.

Gentile, C., Spiller, N. and Noci, G. (2007), "How to sustain the customer experience: an overview of experience components that co-create value with the customer", European Management Journal, Vol. 25, pp. 395-410.

Gilmore, J.H. and Pine, B. II (2002), "Customer experience places: the new offering Frontier”, Strategy and Leadership, Vol. 30, pp. 4-11.

Gupta, A.K., Tesluk, P.E. and Taylor, M.S. (2007), "Innovation at and across multiple levels of analysis", Organization Science, Vol. 18 No. 6, pp. 885-897.

Hair, J.F.J., Ringle, C.M. and Sarstedt, M. (2011), "PLS-SEM: indeed a silver bullet", The Journal of Marketing Theory and Practice, Vol. 19 No. 2, pp. 139-152.

Hair, J.F., Hult, G.T.M., Ringle, C.M. and Sarstedt, M. (2016), A Primer on Partial Least Squares Structural Equation Modeling (PLS-SEM), 2nd ed., Sage, Thousand Oaks, CA.

Harman, H.H. (1967), Modern Factor Analysis, 2nd ed., University of Chicago Press, Chicago, IL.

Hennig-Thurau, T. and Klee, A. (1997), "The impact of customer satisfaction and relationship quality on customer retention: a critical reassessment and model development", Psychology and Marketing, Vol. 14 No. 8, pp. 737-764.

Henseler, J., Ringle, C.M. and Sarstedt, M. (2015), “A new criterion for assessing discriminant validity in variance-based structural equation modelling", Journal of the Academy of Marketing Science, Vol. 43 No. 1, pp. 115-135.

Homburg, C., Jozić, D. and Kuehnl, C. (2017), "Customer experience management: toward implementing an evolving marketing concept", Journal of the Academy of Marketing Science, Vol. 45 No. 3, pp. 377-401, doi: 10.1007/s11747-015-0460-7.

Howard, J.A. and Sheth, J.N. (1969), The Theory of Buyer Behavior, John Wiley, New York.

Jensen, M.B., Johnson, B., Lorenz, E. and Lundvall, B.A. (2007), "Forms of knowledge and modes of innovation", in Lundvall, B.A. (Ed.), The Learning Economy and the Economics of Hope, Anthem Press, London, pp. 155-182.

Johannessen, J., Olsen, B. and Lumpkin, G.T. (2001), "Innovation as newness: what is new, how new, and new to whom?”, European Journal of Innovation Management, Vol. 4 No. 1, pp. 20-31, doi: $10.1108 / 14601060110365547$.

Kim, M. and Lennon, S. (2008), "The effects of visual and verbal information on attitudes and purchase intentions in Internet shopping", Psychology and Marketing, Vol. 25, pp. 146-178.

Kim, S., Cha, J., Knutson, B.J. and Beck, J.A. (2011), "Development and testing of the consumer experience Index (CEI), Managing Service Quality: An International Journal, Vol. 21 No. 2, pp. 112-132, doi: 10.1108/09604521111113429.

Knight, D.K. and Young Kim, E. (2007), "Japanese consumers' need for uniqueness: effects on brand perceptions and purchase intention", Journal of Fashion Marketing and Management: An International Journal, Vol. 11 No. 2, pp. 270-280. 
Kotler, P. (1994), Marketing Management. Analysis, Planning, Implementation, and Control, 8th ed., Prentice-Hall, Englewood Cliffs, NJ.

Kuo, Y.F., Wu, C.M. and Deng, W.J. (2009), "The relationships among service quality, perceived value, customer satisfaction, and post-purchase intention in mobile value-added services", Computers in Human Behavior, Vol. 25 No. 4, pp. 887-896.

Kwortnik, R.J. and Ross, W.T. (2007), "The role of positive emotions in experiential decisions", International Journal of Research in Marketing, Vol. 24, pp. 324-335.

Ledden, L., Kalafatis, S.P. and Mathioudakis, M. (2011), "The idiosyncratic behaviour of service quality, value, satisfaction, and intention to recommend in higher education: an empirical examination", Journal of Marketing Management, Vol. 27 Nos 11-12, pp. 1232-1260.

Lee, S.A. (2018), "Investigating antecedents and outcome of telepresence on a hotel's website", International Journal of Contemporary Hospitality Management, Vol. 30 No. 2, pp. 757-775.

Lehto, X.Y., Shi, Z., Anaya, G.J., Lehto, M.R. and Cai, L. (2018), "Cross-cultural user experience of luxury hotel websites: a conjoint analysis", Tourism, Culture and Communication, Vol. 18 No. 4, pp. 251-274.

Lemon, K.N. and Verhoef, P.C. (2016), "Understanding customer experience throughout the customer journey”, Journal of Marketing, Vol. 80 No. 6, pp. 69-96.

Li, L., Peng, M., Jiang, N. and Law, R. (2017), "An empirical study on the influence of economy hotel website quality on online booking intentions", International Journal of Hospitality Management, Vol. 63, pp. 1-10.

Mathwick, C., Malhotra, N. and Rigdon, E. (2001), "Experiential value: conceptualisation, measurement and application in the catalog and Internet shopping environment", Journal of Retailing, Vol. 77 No. 1, pp. 39-56.

Meyer, C. and Schwager, A. (2007), "Understanding customer experience”, Harvard Business Review, Vol. 85 No. 2, pp. 117-126.

Mkwizu, K.H. (2019), "Digital marketing and tourism: opportunities for Africa", International Hospitality Review, Vol. 34 No. 1, pp. 5-12.

Ng, I.C. and Wakenshaw, S.Y. (2017), "The Internet-of-Things: review and research directions", International Journal of Research in Marketing, Vol. 34 No. 1, pp. 3-21.

Nitzl, C., Roldán, J.L. and Cepeda, G. (2016), "Mediation analysis in partial least squares path modeling: helping researchers discuss more sophisticated models", Industrial Management and Data Systems, Vol. 119 No. 9, pp. 1849-1864.

O'Sullivan, D. and Dooley, L. (2008), Applying Innovation, Sage Publications, Sage, Oaks, CA.

Oliver, R.L. (1999), “Whence customer loyalty?”, Journal of Marketing, Vol. 63 No. 3, pp. 33-44.

Ordanini, A. and Parasuraman, A. (2011), "Service innovation viewed through a service-dominant logic lens: a conceptual framework and empirical analysis", Journal of Service Research, Vol. 14 No. 1, pp. 3-23.

Organisation for Economic Co-Operation and Development (2005), Oslo Manual: Guidelines for Collecting and Interpreting Innovation Data, 3rd ed., OECD Publishing, Paris.

Otto, J.E. and Ritchie, J. (1996), “The service experience in tourism”, Tourism Management, Vol. 17 No. 3, pp. 165-174.

Park, S.Y. and Allen, J.P. (2013), "Responding to online reviews: problem solving and engagement in hotels", Cornell Hospitality Quarterly, Vol. 54 No. 1, pp. 64-73.

Park, E., Kim, K.J. and Kwon, S.J. (2017), “Corporate social responsibility as a determinant of consumer loyalty: an examination of ethical standard, satisfaction, and trust", Journal of Business Research, Vol. 76, pp. 8-13.

Pereira, H.G., de Fátima Salgueiro, M. and Rita, P. (2016), "Online purchase determinants of loyalty: the mediating effect of satisfaction in tourism", Journal of Retailing and Consumer Services, Vol. 30, pp. 279-291. 
Podsakoff, P.M., MacKenzie, S.B., Lee, J.Y. and Podsakoff, N.P. (2003), "Common method biases in behavioral research: a critical review of the literature and recommended remedies", Journal of Applied Psychology, Vol. 88 No. 5, p. 879.

Rahimizhian, S. and Irani, F. (2020), "Contactless hospitality in a post-Covid-19 world”, International Hospitality Review.

Rawson, A., Duncan, E. and Jones, C. (2013), "The truth about customer experience”, Harvard Business Review, Vol. 91, pp. 90-98.

Rayport, J.F. and Jaworski, B.J. (2003), Introduction to E-Commerce, 2nd ed., Mc Graw- Hill Education, New York, NY.

Ringle, C., Da Silva, D. and Bido, D. (2015), "Structural equation modeling with the SmartPLS", Brazilian Journal of Marketing, Vol. 91 No. 2.

Saleem, Z. and Rashid, K. (2011), "Relationship between customer satisfaction and mobile banking adoption in Pakistan", International Journal of Trade, Economics and Finance, Vol. 2 No. 6, p. 537.

Sautter, P., Hyman, M.R. and Lukosius, V. (2004), "E-tail atmospherics: a critique of the literature and model extension", Journal of Electronic Commerce Research, Vol. 5, pp. 14-24.

Schmidt, T. and Rammer, C. (2006), The Determinants and Effects of Technological and Non-technological Innovations: Evidence from the German CIS IV, ZentrumfürEuropäischeWirtschaftsforschung (ZEW), Mannheim.

Schiffman, G.L. and Kanuk, L.L. (2010), Consumer Behavior, 10th ed., Prentice Hall, NJ.

Schumpeter, J.A. (1934), The Theory of Economic Development, Harvard University Press, Cambridge, MA.

Shih, E., Venkatesh, A., Chen, S. and Kruse, E. (2013), "Dynamic use diffusion model in a crossnational context: a comparative study of the United States, Sweden, and India”, Journal of Product Innovation Management, Vol. 30 No. 1, pp. 4-16.

Spohrer, J. (2016), "Innovation for jobs with cognitive assistants: a service science perspective", Disrupting, p. 132.

Statista (2017), "Number of smartphone users worldwide from 2014 to 2020", available at: https:// www.statista.com/statistics/330695/number-of-smartphone-users-worldwide.

Straub, D., Boudreau, M.C. and Gefen, D. (2004), "Validation guidelines for IS positivist research", Communications of the Association for Information Systems, Vol. 13 No. 1, p. 24.

Stringam, B. and Gerdes, J. (2019), "Service gap in hotel website load performance", International Hospitality Review, Vol. 33 No. 1, pp. 16-29.

Taylor, S. and Todd, P. (1995), "Decomposition and crossover effects in the theory of planned behavior: a study of consumer adoption intentions", International Journal of Research in Marketing, Vol. 12 No. 2, pp. 137-155.

Tolba, A. (2011), "The impact of distribution intensity on brand preference and brand loyalty", International Journal of Marketing Studies, Vol. 3 No. 3, pp. 56-66.

Tortosa, V., Moliner, M.A. and Sanchez, J. (2009), "Internal market orientation and its influence on organisational performance", European Journal of Marketing, Vol. 43 Nos 11/12, pp. 1435-1456.

Tynan, C., McKechnie, S. and Chhuon, C. (2010), Co-creating Value for Luxury Brands.

Vargo, S.L. and Lusch, R.F. (2004), "Evolving to a new dominant logic of marketing", Journal of Marketing, Vol. 68, pp. 1-17.

Venkatesh, V., Thong, J.Y. and Xu, X. (2012), "Consumer acceptance and use of information technology: extending the unified theory of acceptance and use of technology", MIS Quarterly, Vol. 36 No. 1, pp. 157-178.

Verhoef, P., Lemon, K.N., Parasuraman, A., Roggeveen, A., Tsiros, M. and Schlesinger, L.A. (2009), "Customer experience creation: determinants, dynamics and management strategies", Journal of Retailing, Vol. 85, pp. 31-41. 
Vermesan, O. and Friess, P. (Eds) (2013), Internet of Things: Converging Technologies for Smart Environments and Integrated Ecosystems, River Publishers, Aalborg.

Vermesan, O. and Friess, P. (Eds) (2014), Internet of Things-From Research and Innovation to Market Deployment, River Publishers, Aalborg, Vol. 29.

Voss, K.E., Spangenberg, E.R. and Grohmann, B. (2003), "Measuring the hedonic and utilitarian dimensions of consumer attitude", Journal of Marketing Research, Vol. 40 No. 3, pp. 310-320.

Voss, C., Roth, A.V. and Chase, R.B. (2008), "Experience, service operations strategy, and services as destinations: foundations and exploratory investigation", Production and Operations Management, Vol. 17, pp. 247-266.

Wold, H. (1982), "Soft modeling: the basic design and some extensions", in Jöreskog, K.G. and Wold, H. (Eds), Systems under Indirect Observations: Part II, North-Holland, Amsterdam, pp. 1-54.

Woodruff, R.B. (1997), "Customer value: the next source for competitive advantage", Journal of the Academy of Marketing Science, Vol. 25, pp. 139-153.

Woodruff, R.B. and Gardial, S. (1996), Know Your Customer: New Approaches to Understanding Customer Value and Satisfaction, Wiley Blackwell, Cambridge, MA.

Wu, L.Y., Chen, K.Y., Chen, P.Y. and Cheng, S.L. (2014), "Perceived value, transaction cost, and repurchase-intention in online shopping: a relational exchange perspective", Journal of Business Research, Vol. 67 No. 1, pp. 2768-2776.

Xiang, Z. and Gretzel, U. (2010), "Role of social media in online travel information search", Tourism Management, Vol. 31 No. 2, pp. 179-188.

$\mathrm{Xu}, \mathrm{C}$., Peak, D. and Prybutok, V. (2015), "A customer value, satisfaction, and loyalty perspective of mobile application recommendations", Decision Support Systems, Vol. 79, pp. 171-183.

Yoo, Y., Lyytinen, K., Boland, R., Berente, N., Gaskin, J., Schutz, D. and Srinivasan, N. (2010), "The next wave of digital innovation: opportunities and challenges", in Research Workshop: Digital Challenges in Innovation Research, pp. 1-37.

Zeithaml, V. (1988), "Consumer perceptions of price, quality, and value: a means-end model and synthesis of evidence", Journal of Marketing, Vol. 52, pp. 2-22.

Zeithaml, V.A., Berry, L.L. and Parasuraman, A. (1996), "The behavioral consequences of service quality”, Journal of Marketing, Vol. 60, pp. 31-46.

Zervas, G., Proserpio, D. and Byers, J.W. (2017), "The rise of the sharing economy: estimating the impact of Airbnb on the hotel industry", Journal of Marketing Research, Vol. 54 No. 5, pp. 687-705.

Zhang, Y., Fiore, A.M., Zhang, L. and Liu, X. (2021), "Impact of website design features on experiential value and patronage intention toward online mass customization sites", Journal of Fashion Marketing and Management, Vol. 25 No. 2, pp. 205-223, doi: 10.1108/JFMM-11-2019-0261.

\section{Further reading}

Baron, R.M. and Kenny, D.A. (1986), "The moderator-mediator variable distinction in social psychological research: conceptual, strategic, and statistical considerations", Journal of Personality and Social Psychology, Vol. 51 No. 6, p. 1173.

MacKenzie, S.B. and Podsakoff, P.M. (2012), "Common method bias in marketing: causes, mechanisms, and procedural remedies", Journal of Retailing, Vol. 88 No. 4, pp. 542-555.

Sheth, J.N. and Howard, J.A. (1969), The Theory of Buyer Behaviour, Wiley, New York.

\section{Other Resources}

World Travel and Tourism Council Website (wttc.org) 


\section{Supplementary Information}

The supplementary file is available online for this article.

\section{Corresponding author}

Joshua Kofi Doe can be contacted at: dlas1274@yahoo.com

For instructions on how to order reprints of this article, please visit our website: www.emeraldgrouppublishing.com/licensing/reprints.htm Or contact us for further details: permissions@emeraldinsight.com 